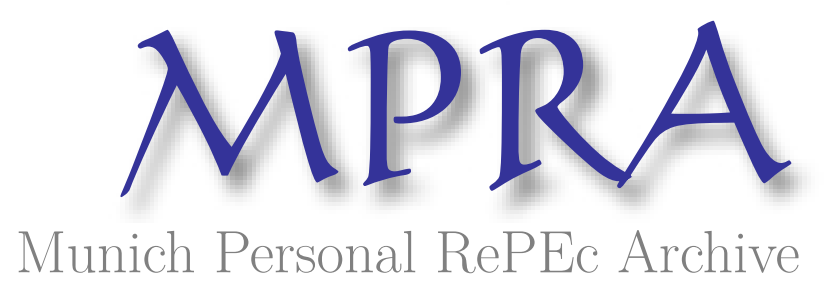

\title{
Openness to Trade and Structural Changes in the Sources of Economic Growth and Labour Demand in Turkey
}

Guncavdi, Oner and Kucukcifci, Suat

Istanbul Technical University - Faculty of Management

7 July 2008

Online at https://mpra.ub.uni-muenchen.de/9624/

MPRA Paper No. 9624, posted 19 Jul 2008 08:26 UTC 


\title{
Openness to Trade and Structural Changes in the Sources of Economic Growth and Labour Demand in Turkey
}

\begin{abstract}
The Turkish economy has undergone drastic structural changes since 1980. While the effects of the Turkish adjustment programme have drawn considerable attention, a few studies have investigated its employment impacts. Unlike neoclassical expectation behind the structural adjustment programme, some studies for Turkey have showed that this policy change in 1980 caused a decline in employment. Results show that the Turkish industrialisation strategy cannot be regarded as export-led industrialisation strategy. Extra output created by exports has been very limited during the post-liberalisation period. However domestic final demand has continued to be the most dominant determinant of output growth. A Surprising result of the paper appears for the period of 1985-1990 when import substitution in final demand created output growth particularly in technology-intensive manufacturing and other manufacturing sectors. However import penetration in final and intermediate goods overwhelmingly important factors creating deindustrialisation in the period of 1990-1996. This paper, however, examines the sources of changes in employment. Despite neoclassical expectations, the reform period after 1982 witnessed large factor substitution against labour, even in the tradable goods sector. Additionally, labour demand also appears to response to output growth less in the post-liberalisation period than before.
\end{abstract}

JEL Classification Number: D57, F14, O16, R15

Key Words : Structural changes, employment, input-output, trade reform, Turkey

\section{Introduction}

The Turkish economy has recently been undergoing intense after-shocks of two sucessive financial crashes in 2000 and 2001. Although the economic crises stemmed primarily from the financial sector, there is also increasing concern about the role of integrating the Turkish economy fully into the world economy in these recent problems. In this regard we arise the issue of whether liberalised trade regimes have generated a significant dynamics for economic growth and employment in Turkey.

Turkey has undergone drastic structural changes in her economy since the beginning of the 1980s. In the inhospitable international setting of the pre-1980 period, Turkey had pursed an inward-oriented industrialisation strategy, which was supported by a high degree of protection, exchange rate controls, negative 
real interest rates etc. However, this strategy was followed by severe balance of payment crises in 1979, which arose basically from the low level of exports and heavy dependence on imported capital and intermediate goods. International organisations, such as the International Monetary Funds (IMF) and World Bank, then urged Turkey to adopt a more outward-oriented development strategy emphasising greater reliance on market mechanism, reductions in barriers to imports and removal of all distortions that cause internal relative prices to deviate from the relative world prices. The Turkish structural changes in economic policies were far reaching, and can be attributed to some extent to trade reforms. The expectation from the liberalisation of the foreign trade was that increasing foreign trade would improve the allocation of economic resources and would encourage the domestic production. With various incentive measures and competitive foreign exchange rate, exports additionally were expected to take over a greater share in the international markets in favour of the Turkish tradeable goods.

In the post-reform period, the Turkish economy has been exposed to fluctuations in the world economy for nearly 20 years with liberal trade policies, and arises some concerns about whether international trade has helped the Turkish economy for (de)industrialisation. This paper accordingly attempts to examine changes in compositional structural change of the economy as a consequent of trade reform, and measures the extent of which trade-related factors were accounted for these changes. Compositional structural changes particularly allow us to analyse the changes in the relative importance of different demand factors in creating output and employment in the pre- and postliberalisation periods.

The effects of structural adjustment programme in Turkey have been examined by various studies (see Arıcanlı and Rodrik, 1990, Günçavdı, Bleaney and McKay, 1999), but a few has put particular emphasis on the employment effects of structural adjustment programme (e.g. Günçavdı and Küçükçifçi, 2001, Günçavdı, Küçükçifçi and McKay, 2001, Günlük-Şenesen, 1998 and Yentürk, 1997). The Turkish structural adjustment programme aimed to increase the production of tradeable goods, while reducing their domestic consumption, so bringing about external balance. The measures of the programme included both those, which are likely to have adverse employment effects, such as fiscal contraction, import competition etc., and others which are likely have favourable impacts on employment, such as increases in production of exportation and the 
production of tradeable goods (Rodrik, 1999). The net effect is, however, a matter of empirical investigation. The theory behind Structural Adjustment Programmes is provided by the conventional Heckscher-Ohlin $(H-O)$ Theorem. This theorem predicts that countries will tend to be net exporters of their abundant factors and net importers of their scare factors. Previous studies for Turkey have consistently showed that the structural adjustment programme and trade reform as an integral part of it were ineffective creating additional employment in this expected direction for the labour abundant Turkish economy and, in fact, caused an economy-wide decline in employment in the proadjustment period (Günçavdı and Küçükçifçi, 2001, Günlük-Şenesen, 1998 and Yentürk, 1997). However, none of them has explicitly investigated the sources behind this decline in employment in the adjustment period. In this study we investigate the role of various trade-related factors in the losses (or gains) in output and employment, and introduce a methodology to measure the changing role of these factors in sectoral and total output growth.

The remainder of the paper is organised as follows. The following section highlights the main aspects of economic development in the Turkish economy. In Section II the methodology is introduced to identify the sources of the changes in economic growth and employment. Section IV presents the sources of data and the results derived for total and sectoral level of the Turkish economy. Section V gives concluding comments.

\section{Economic Background and Trade Reform in Turkey}

After two decades of experience with the import-substituting industrialisation strategy the Turkish economy has undergone radical economic reforms towards relatively more open, outward-oriented strategy with increasing reliance on the guidance of the market mechanism (see Celasun and Rodrik, 1989; Arıcanlı and Rodrik, 1990). In the pre-reform period Turkish development strategies had been based upon the premise that industrialisation was essential and could be encouraged only through policies that protected the domestic firms from foreign competition. Accordingly in the sectors where the domestic production flourished, imports had been restricted through various quantity restrictions (see 
Baysan and Blitzer, 1990). ${ }^{1}$ The Turkish economy, however, enjoyed this strategy with very high growth rates until 1976, which was 7.2 per cent on average for the period of 1973-1976 (see Table 1). The public sector was the deriving force behind this economic growth, relying largely upon expansion of public demand and investment boom (see Celasun, 1990). Import demand required for ambitious growth rates, as a consequence, was growing much more rapidly than exports, and was thus worsening balance of payment of the country and leading the economy to being increasingly dependent on foreign borrowing. When the country's balance of payment position worsened the widely-used means of external adjustment in the pre-reform period were the use of international reserve (if available), restricting imports through highly protective trade regime, and when imbalances reached unsustainable levels, sizeable devaluations of the Turkish lira (see Metin-Özcan et al., 2001). ${ }^{2}$ In the 1977-1980 period, the economy growth virtually collapsed to 1.3 per cent on average (see Table 1), mainly because of supply-side bottlenecks imposed by unfavourable international setting of the time (see Bilginsoy, 1993).

\section{(Table 1 about here)}

Under the trade regime prior to 1980, imports were subject to discretionary import licensing, along with restrictions, which governed the utilisation and allocation of foreign exchange. Protection was further intensified by extremely high levels of tariffs across the border. In this macroeconomic setting, there was little incentive for exports, given the high profitability of producing for the domestic market. Furthermore, this protection system, which became increasingly complex over time, led to the elimination of the possibility of competition in the domestic markets, and hence contributed to high levels of inefficiency in the economy (see Krueger and Aktan, 1992 for detail).

Monetary policies in the same period were very much designed for complementing the trade regime and the industrialisation. Until 1982, the Turkish financial markets had been considered as financially repressed with intensive government involvements into financial markets in the forms of fixing

${ }^{1}$ Krueger and Aktan (1992) demostrate that the shift in the restrictiveness of import licensing over the 1979-1988 period. They report that the number of commodities subject to any form of licensing fell sharply from 1600 in 1979 to 33 in 1988.

2 As a consequence of restrictive trade regime and the fixed exchange rate policy, the Turkish lira appreciated in real term against the US dollar by 23 per cent between 1975 and 1979 (Krueger and Aktan, 1992). In 1980, however devaluation of $T L$ reached to 144 percent in nominal, giving rise to 
interest rate and exchange rates, heavy tax burden on financial earnings, high liquidity and reserve requirement ratios, limiting the entry to the financial markets. Control was also exercised on the allocation of credit by public ownership of financial institutions providing long-run loan to the privileged private sector (see e.g. Akyüz, 1990; Atiyas and Ersel, 1995).

Starting from 1980 Turkey embarked on a series of policy reforms under the auspices of international institutions such as the IMF and the World Bank. Between 1980 and 1984, the World Bank granted Turkey five one-year structural adjustment loans (SALs), amounting to $\$ 1.6$ billion, which were all used in supporting policy reforms (Kirkpatrick and Öniş, 1991). The great extent of reforms took place in the period of 1980-1986, and involved in trade and foreign exchange regimes and price reform aiming at reducing public involvement in commodity and financial markets. On the finance side, financial liberalisation become an integral part of overall reform programme. Financial reforms initially aimed at eliminating exogenous constraints, which had been created by intensive public involvement and administratively controlled interest rates. First interest rates were freed, allowing real interest to become positive in the pro-reform period. New financial institutions were introduced with a premise that they improve the efficiency of financial markets and the allocation of financial resources among alternative uses. The restrictions on the entry into the Turkish banking sector were removed.

As another integral part of the reform, the government implemented a rather gradual trade liberalisation because of the worry that a rapid import liberalisation would deteriorate the balance of payments condition of the country. The trade reform between 1980 and 1985 aimed at eliminating quantitative controls on imports (such as quota and licensing system), and included the reduction of stamp duty from 25 percent to 1 percent, gradual shifting of goods from most restrictive List II to liberalised List I (see Baysan and Blitzer, 1991 and Olgun and Togan, 1990). In January 1995, Turkey finally joined the custom union and eased foreign trade with European Union. The export promotion strategy was implemented by introducing a number of export incentives including tax rebates, subsidised credit and foreign exchange allocation that allowed for the duty-free import of raw materials. 3 An

a 30 percent real devaluation with 100 per cent inflation in the same year (see Bzysan and Blitzer, 1990).

3 The total value of direct incentives given to exporters reached, on average, 23.4 percent of total exports in 1983 (Baysan and Blitzer, 1990). 
improvement in the balance of payments was of great importance to the government, first to gain international creditworthiness, then to compensate for the depressed domestic demand due to the austerity programme.

The economy responded to these changes in economic policies in the beginning very well. Exports grew very rapidly, at an annual rate 24 percent, in the early reform period of 1980-1985 (see SIS, 1994). The economy-wide exportGNP ratio rose from 4.2 percent in 1980 to nearly 12 percent in 1985 . The composition of exports also drastically changed. The share of industrial good exports rose from 36 percent of total exports in 1980 to 75 percent in 1985, while that of agricultural exports, which had been the traditional export sector in Turkey for many years before the reforms, declined from 57.5 percent in 1980 to 21.6 percent in 1985. Following the import liberalisation, imports increased substantially at an annual growth rate of 56 percent from 1979 to 1980 . The most striking feature of imports figures is the observation of a rapid increase in the share of the importation of consumption goods from 2.1 percent in 1980 to 8.6 percent in 1986. In the second phase of the reform in the period 1987-1990, the ratio of exports to imports increased to 71 percent from almost 64 percent in the initial period 1980-1985.

\section{(Table 2 about here)}

This drastic structural change in the economy is shown in Table 2, which reports the shares of sectoral production levels in GDP over the period of 19631996. The most drastic feature of the change was the enormous decline in the share of agricultural output from 36 per cent in the period of 1968-1973 to nearly 16 percent in the period of 1991-1996. The share of service output, on the other hand, showed a substantial rise from 36 per cent in 1968-1973 to 46 per cent in the period of 1991-1996.

It is clear from the discussion above that the Turkish economy underwent a series of radical institutional and structural changes in the 1980 s and 1990s. It is also obvious that changes in the trade regime of the country were crucial element of these radical changes. However, after nearly 20 years of experiences with liberal trade policies the Turkish trade regime still raises some concerns about its contribution to economic problems that the country has recently encountered. In what follows we introduce the methodology to measure the extent of which changes in trade regime influence (de)industrialisation through output growth and employment generation. 


\section{Methodology}

In this section we introduce the accounting approach to the analysis of patterns of economic growth pioneered by Chenery et al. (1962) using input-output framework (also see Gregory et al., 2001; Albala-Bertrand, 1999; Schumann, 1990; Chenery et al., 1986; and Feldman et al., 1987). We then apply this framework to the Turkish input-output tables in order to investigate the sources of economic growth in the Turkish economy.

Input-output models are based on some restrictive assumptions of fixed input-output coefficients with constant returns to scale, fixed factor shares in production and perfectly elastic supplies of factors of production (see BulmerThomas, 1982). The Leontief production function is often criticised for its assumption of fixed coefficients in input use. Since we utilise input-output tables observed at two separate dates we obtain direct measures of the change in input use over time. Therefore, the only necessary assumption on the production function is constant returns to scale across all inputs at each point in time. The model and its derivation are introduced in the following section.

\section{(a) The source of Changes in Gross Output}

In a standard input-output framework the flows of all goods in an economy with $n$ industries can be written as follows:

$$
\mathbf{x}=(\mathbf{I}-\mathbf{A})^{-1}(\mathbf{f}+\mathbf{e})
$$

where $\mathbf{I}$ and $\mathbf{A}$ respectively are the unit matrix and the matrix of input-output coefficients, whose element $a_{i j}$ represents the unit-input requirement of the $i^{\text {th }}$ industry for the output of the $j^{\text {th }}$ industry, all with $(n \times n)$ dimension. $\mathbf{x}$ is the column vector of sectoral production, with $(n \times 1)$ dimension. $\mathbf{f}$ and $\mathbf{e}$, respectively, are the vectors of total final demand and exports, both with $(n \times 1)$ dimension.

The balance equation for the flow of domestic output can be written as follows:

$$
\mathbf{x}=\mathbf{w}^{\mathbf{d}}+\mathbf{f}^{d}+\mathbf{e}
$$


where $\mathbf{f}^{\mathrm{d}}$ : the vector of flows of domestic final use; $\mathbf{w}^{\mathrm{d}}$ : the vector of flows to domestic intermediate use, which is given by:

$$
\mathbf{w}^{\mathbf{d}}=\mathbf{A}^{\mathbf{d}} \mathbf{x}
$$

Upon substituting (3) into (2),

$$
\mathbf{x}=\mathbf{A}^{\mathbf{d}} \mathbf{x}+\mathbf{f}^{d}+\mathbf{e}
$$

Imports are included in this framework by assuming that imported goods for intermediate and final uses are in fixed proportion of total. In other words,

$$
\mathbf{A}^{d}=\mathbf{h} \mathbf{A} \text { and } \mathbf{f}^{d}=\mathbf{s f}
$$

where $\mathbf{A}^{d}$ : the matrix of domestic input-output coefficients, h: domestic supply ratio in intermediate uses, $\mathbf{s}$ : domestic supply ratio in final uses. Substituting (4) into (3) renders the following:

$$
\mathbf{x}=\mathbf{h A x}+\mathbf{s f}+\mathbf{e}
$$

Solving (6) with respect to $\mathbf{x}$ gives

$$
\mathbf{x}=(\mathbf{I}-\mathbf{h} \mathbf{A})^{-1}(\mathbf{s f}+\mathbf{e})
$$

This relationship holds for any point in time, and differencing it with respect to time and rearranging the resulting expression give us the change in gross output between any two periods of time. This final expression allows us explicitly to see the sources of these changes in gross output as follows:

$$
\Delta \mathbf{x}=\mathbf{R} \Delta \mathbf{s f}+\mathbf{R s} \Delta \mathbf{f}+\mathbf{R} \Delta \mathbf{e}+\mathbf{R} \Delta \mathbf{h A x}+\mathbf{R h} \Delta \mathbf{A x}
$$

where $\Delta$ denotes the change over time; $\mathbf{R}=(\mathbf{I}-\mathbf{h A})^{-1}$ is the Leontief inverse matrix. The level terms in equation (8) can be evaluated as beginning and end values, which are similar to Paasche and Laspeyres index weighting. The derivation of the formula for either use is analogous and yields the following two results for Paasche and Laspeyres index weighting respectively:4

$$
\begin{aligned}
& \Delta \mathbf{x}=\mathbf{R}_{1} \Delta \mathbf{s f}_{0}+\mathbf{R}_{1} \mathbf{s}_{1} \Delta \mathbf{f}+\mathbf{R}_{1} \Delta \mathbf{e}+\mathbf{R}_{1} \Delta \mathbf{h} \mathbf{A}_{0} \mathbf{x}_{0}+\mathbf{R}_{1} \mathbf{h}_{0} \Delta \mathbf{A} \mathbf{x}_{0} \\
& \Delta \mathbf{x}=\mathbf{R}_{0} \Delta \mathbf{s} \mathbf{f}_{1}+\mathbf{R}_{0} \mathbf{s}_{0} \Delta \mathbf{f}+\mathbf{R}_{0} \Delta \mathbf{e}+\mathbf{R}_{0} \Delta \mathbf{h} \mathbf{A}_{1} \mathbf{x}_{1}+\mathbf{R}_{0} \mathbf{h}_{0} \Delta \mathbf{A} \mathbf{x}_{1}
\end{aligned}
$$


where the subscript $O$ and 1 represent the initial and terminal years respectively. Equation (9) allocates the change in gross output among changes in the various components of its use: the changes in domestic final demand $(\Delta \mathbf{f})$; the changes in exports $(\Delta \mathbf{e})$; the changes in the home shares in final consumption (import substitution in final demand) ( $\Delta \mathbf{s})$; and the changes in the home shares in intermediate goods (import substitution in intermediate goods) $(\Delta \mathbf{h})$. The term $\Delta \mathbf{A}$ explicitly allows the input-use coefficients to vary over time in a way that will be determined by the data. These changes in Leontief coefficients are interpreted as technical changes in the production. In what follows, equation (9) is then applied to the data of the Turkish economy.

\section{(b) Output Growth and Employment}

Our interest is in assessing the sources of changes in employment in the Turkish economy over a time period. In doing so, we extend the derivations in the previous section towards decomposing the sources of sectoral employment demand. We implicitly assume that changes in employment are due to output growth and factor substitution in production. Therefore the factors that cause to change gross output can also be considered as the sources of changes in employment. Total labour requirements of producing $\mathbf{x}$ are given by:

$$
\mathbf{L}=\mathbf{l} \mathbf{x}
$$

where $\mathbf{L}$ is the vector of sectoral employment levels, $\mathbf{l}$ is the vector of employment coefficients required in the production of unit output (expressed as a diagonal matrix). Similarly we difference (15) with respect to time to measure the sources of changes in employment as follows:

$$
\Delta \mathbf{L}=\mathbf{L}_{1}-\mathbf{L}_{\mathbf{0}}
$$

where $O$ and 1 represent the initial and terminal points in time. To be comparability with the earlier derivation we use the Laspeyres weighting, and derive the following:

$$
\Delta \mathbf{L}=\mathbf{l}_{\mathbf{0}} \Delta \mathbf{X}+\Delta \mathbf{l} \mathbf{X}_{\mathbf{1}}
$$

4 The formal derivation in detail is available in Appendix A 
In equation (17), changes in demand for employment can be attributed to two different sources; namely changes in sectoral gross output at constant labour use (the first term on the right-hand side), and changes in the use of labour per unit output (the second term on the right-hand side). Substituting (14) into (17) allows us to see the allocation of changes in demand for employment across the various sources of output on the one hand, and labour requirements per unit of output on the other.

$$
\Delta \mathbf{L}=\left(\mathbf{l}_{\mathbf{0}} \mathbf{R}_{\mathbf{0}} \Delta \mathbf{s} \mathbf{f}_{\mathbf{1}}+\mathbf{l}_{\mathbf{0}} \mathbf{R}_{\mathbf{0}} \mathbf{s}_{\mathbf{0}} \Delta \mathbf{f}+\mathbf{l}_{\mathbf{0}} \mathbf{R}_{\mathbf{0}} \Delta \mathbf{e}+\mathbf{l}_{\mathbf{0}} \mathbf{R}_{\mathbf{0}} \Delta \mathbf{h} \mathbf{A}_{\mathbf{1}} \mathbf{x}_{1}+\mathbf{l}_{\mathbf{0}} \mathbf{R}_{\mathbf{0}} \mathbf{h}_{\mathbf{0}} \Delta \mathbf{A} \mathbf{x}_{1}\right)+\Delta \mathbf{l} \mathbf{x}_{\mathbf{1}}
$$

Equation (18) is the expression, showing that changes in employment are associated with the evaluation of the various constituents of demand and technology. The results of this analysis are presented in Section IV.

\section{Empirical Results}

\section{(a) Data}

Our analysis is based on the input-output tables for the years 1973, 1985, 1990 and 1996. Our focus on these four years was primarily dictated by the availability and reliability of detailed data on input-output tables. Although another table is available for 1979, the analysis based on this table lacks credibility because this year was a year of foreign exchange shortage, which caused various constraints on the supply side of the economy (see Bilginsoy, 1993). These three papers, however, are candidates of reflecting the different phases of the Turkish economy. The first table, for example, compromises structural information regarding the inward-oriented strategy before 1980. In order to see the structural changes after the reform, other tables can be used. The table for 1985 represents the economic structure just after the initial reforms, whereas information on the economy after the capital account liberalisation can be extracted from the table for 1990. The distortions created by the effects of increased public involvement in capital markets and large capital flows could be captured in the recently published 1996 table.

The first three input-output tables for Turkey contain 64 industries while the last one for 1996 possesses only 97 sectors. However, the number of sectors must be reduced to 24 because price indices and employment data used in this 
study are available only for 24 sectors. Sectoral employment data in Turkey are collected from different sources, and typically cover formal employment figures which are recorded by the Social Insurance Agency and the Civil Servants' Pension Funds (see Celasun, 1989 for detail). However the use of informal labour is widespread in the Turkish economy (see Özar, 1995; Köse and Yeldan, 1996; Yeldan, 2000 for further discussion). For example, Günlük-Şenesen (1998) estimated that the use of informal labour in 1990 is 98 per cent of total employment in agriculture, 44 per cent in manufacturing and 48 per cent in services. The estimated figures on the use of labour (including formal and informal) in all 24 industries are borrowed from Günlük-Şenesen (1998) for the year 1973 and 1990, and these figures show consistency with the estimates of similar figures in Köse and Yeldan (1996). Employment data for 1985 and 1996 have been compiled from Household Labour Force Survey Results April 1998 by the authors and adjusted according to Günlük-Şenesen (1998) for the inclusion of the informal labour force (see SIS, 1998).

Our analysis is based on aggregated tables by commodity groups, rather than industry by industry input-output tables. All sectors are classified to seven aggregate sectors; namely primary and extractive sectors, primary manufacturing, technology-intensive manufacturing, other manufacturing, less tradeable services, more tradeable services and financial services. The intertemporal comparison of input-output tables for different years necessitates handling changes in price levels, particularly in any study involving a highly inflationary country such as Turkey. All data used in our analysis have therefore been deflated to 1973 prices (see Appendix B). It must be noted that the price indices for services are implicit GNP deflator computed from State Institute of Statistics (SIS). Further details about data and aggregation are given in Appendix $C$.

\section{(b) Results}

The losses (or gains) of output and employment in the Turkish economy as a result of foreign trade can be attributed to some trade-related factors such as import penetration and substitution effects and exports along with changes in technology and final demand. After the trade liberalisation foreign trade become easier, and an increase in import competition could cause the domestic production to loose market share with a likely decline in output and employment. Import substitution, on the other hand, encourages domestic production of 
formally imported goods, and positively contributed to the sectoral as well as total output levels. Exports, in this regard, are expected to contribute to output positively and may increase employment level dependent on the production technology of the domestic economy. Understanding which of these effects has contributed most directly to changes in output and employment is crucial to assessing the nature of (de) industrialisation in Turkey. In this section we examine the role of each of these factors in output growth and changes in employment using the methodology introduced in Section III.

The first group of our results is shown in Table 3, which reports the shares and growth rates of sectoral output aggregated by commodity groups. Over the entire period between 1973 and 1996, the economy seems to have grown on average by 6.5 percent per annum. The striking feature of the growth rates over the entire period is that the economy grew more rapid in the period of 1985-1990 than others, with 8.7 percent growth rate on average. This can be attributed to expansionary macroeconomic policies, which became feasible after the capital account liberalisation in 1989. However the growth performance of the economy dropped drastically in the last period of 1990-1996, particularly with the influence of Gulf War in 1991 and the economic crises in 1994.

After the implementation of the structural adjustment programme, it was expected that new incentive structure encouraged the production of mostly tradeable goods. In the first sub-period in the table, corresponding to the initial stage of the programme, the growth performances of the sectors like primary \& extractive and the finance sectors appear not to have been particularly impressive due to the growth rates lower than the entire economy. However the sector that can be considered as relatively technology intensive performed better than the entire economy in the period of 1973-1985 with the only exception of the growth of more tradeable service sector. This performance caused a substantial rise in output share of the technology manufacturer in 1985. In the following period of 1985-1990, the less tradeable service sectors grew relatively more rapid than the entire economy with 10 percent growth rate per annum on average, and led the share of this sector in total output to a slight increase from 1985 to 1990 . With the 26 percent share the less tradeable service output become the largest sectoral production in the Turkish economy in 1996.

(Table 3 about here) 
Somewhat surprisingly the performance of the financial sector was disappointing especially in the second sub-period of 1985-1990. Although various incentive measures were undertaken along with deregulation in the financial sector in the early 1980 s, its growth rate appear to be 5 percent, second lowest in the economy after the primary and extractive sectors, and then sharply declined by almost 50 percent in the period of 1985-1990. The share of financial output also continuously declined in the post-liberalisation period. The high technology manufacturing sector grew in the same period more slowly than total output. The other manufacturing sector first slumped in the early stage of reform and then revived in the last sub-period.

Output growth exhibits a great fluctuation in the entire economy. After a 6.2 percent rate in the first sub-period, growth revived substantially and then slumped to 5 percent. To examine the causes of this fluctuation we decomposed the output growth rates into five different sources as defined in the previous section, and report them in Table (4a) and (4b).The results in the tables are based on two different weighting, namely Laspeyres and Paasche. Each table consists of four different panel corresponding to three sub-periods and the entire period. The sources of growth are shown in the columns of the tables. Figures in the tables are the percentage shares of each source in the total output growth.

\section{(Table $4 a$ and $4 b$ about here)}

Decomposition of the changes (Table $4 \mathrm{a}^{5}{ }^{5}$ reveals that over the whole period, final demand, exports, home share in final demand (i.e. import substitution) and the changes in Leontief coefficients were positive influences for output growth, and falling home share in intermediate goods was a negative influence. The growth of domestic final demand made the largest contribution to total output growth with the nearly 77 percent share. The extra unit of exports generated the second largest impact on total output, and this was followed by import substitutions in intermediate goods. Also the production technology in the entire period appears to have changed in a way of demanding more domestic production, and caused to increase total output in the economy.

There were also differences between sub-periods. Somewhat surprisingly the impact of import penetration due to trade liberalisation was not as much as

5 Table 4 includes the results calculated by using two different weighting. Since the qualitative results for both weighting appear to render the similar interpretation, our analysis is only based on the results of Laspeyres weighting. 
expected in the 1973-1985 period. On the contrary import substitution in final demand had almost 8 percent share in changes in total output while import penetration in intermediate goods was responsible only 1 percent decline in output. This finding is particularly important because an easying import with trade reform was expected to increase import penetration. We must also note that the period of 1973-1985 include the period of import-substitution strategy until 1980 and exposed to the output generation effects of this strategy. However, import penetration did not appear to be discouraging factor in output growth even in the post-liberalisation period of 1985-1990. Exports on the other hand in the same period accounted for only 25 percent of total changes in output. It can be considered as the contribution of the Turkish trade reform and export promotion policies to this output growth.

\section{(Table 5 about here)}

Table 5 reports better presentation of the evidence regarding the role of the trade-related sources of output growth. The formation of Table 5 is based on the numerical results shown in Table 4. As presented earlier, foreign trade may influence output growth through three distinctive channels, which can be regarded as the trade-related sources of output growth; namely exports (foreign demand for Turkish goods), import substitution and import penetration (or competition). Increases in first two sources encourage the domestic production while a rise in the import competition is expected to decreases it. Any sources of growth written bold in each cell represents the most dominant factors that influence the domestic production. In the period of 1973-1996, for example, exports and import substitution in final goods appear to be the most dominant two factors on the sectoral output growth for the primary and extractive sector. Although import penetration seems to have discouraged domestic production substantially (by 12 percent in Table 4a), this effect cancelled out by the sum of the positive contributions created by exports and import substitution in final demand. In the entire period between 1973 and 1996, the foreign trade (through exports, import substitution in final goods and import penetration in intermediate goods) can be accounted for the 22.3 percent $^{6}$ of overall output growth in the Turkish economy. Foreign trade seems to explain 32 percent of

\footnotetext{
6 The numerical value of the share of the trade was calculated form the values in Table $4 a$. In particularly 22.3 percent was derived from the sum of the share of exports, 20.4 percent, the share of import substitution, 6.6 and the share of import penetration, -4.7 percent
} 
output growth in the first-sub-period of 1973-1985 while only 2 percent in the period of 1985-1990. Despite a small increase in this share, it still very difficult to express with nearly 8 percent share that the Turkish output growth was tradedriven growth. It seems from our results that the Turkish domestic production has been competing with foreign goods which penetrated the Turkish market substantially and discouraged 25 percent of domestic production in the period of 1990-1996.

\section{(c) Structural changes and demand for labour}

Table 6 contains the decomposition of the employment change as noted in equation (17), which reveals the impacts of changing technology and business organisation on the demand for labour. As seen in the table employment generation effects of gross output are largely counterbalanced by decreasing labour-input requirement per unit of gross output. Labour-saving technology and factor substitution in favour of capital play major role in these negative effects of change in employment-output ratio.

\section{(Table $6 a$ and $6 b$ are about here)}

Closer examinations of the sub-periods of 1973-1996 gives rise to the fact that the employment-generation ability of the economy drastically declined over time. While employment grew 20 percent in the period of 1973-1985, this growth rate dramatically felt to 9 percent in the period of 1985-1990, and then rose to 12 percent in the last period (yet it did not reach to its initial level). It is clear from this evidence that the Turkish economy, overall, lost its employment generation ability in the post-liberalisation period.

This undistinguished performance of the economy appears to have resulted from two separated factors, namely employment generation effects of output growth and changes in employment-income ratio. Considering the former effect, demand for labour seems to response to output growth eventually less than the pre-liberalisation period. It is also evident from Table $6 a$ that factor substitution appears to have taken place in favour of capital, rather than labour.

In a sectoral investigation, the finance sector comes forward with its 250 percent total change in employment in the period of 1973-1985. This is particularly crucial because factor substitution was the primary source of employment generated with its 175 percent. The output growth in this sector led 
only 75 percent of labour demand in this period. This distinguished record of the finance sector went along with liberalisation efforts of the sector after 1982. However, this trend dramatically changed in the period of 1985-1990. The positive and substantial effect of factor substitution reversed and led to almost 2 percent decline in labour demand in the sector.

The less tradeable goods sector became the second leading sources of employment in the economy in the first port-liberalisation period with the growth rates 62 percent in the 1973-1985 period and 21 percent in the period of 19851990. Interestingly this leading role took place in the period where the incentive structure of the economy changed in favour of tradeable and production of the non-tradeable was expected to have declined.

Another interesting result of Table $6 \mathrm{a}$ is that factor substitution took place, to great extent, against labour in the post-liberalisation period. Among other sectors, this is especially important for the tradeable sector. This is because the export-promotion policy adopted in the early 1980 was expected to encouraged labour intensive export goods. However, the results in Table 6a indicate that the factor component of the tradeable goods sector changed against labour in the period of 1985-1990. This particular result is consistent with Günçavdı and Küçükçifçi (2001) and Günçavdı et al. (2001).

\section{Conclusion}

The effect of foreign trade has been substantially high and positive on the domestic production in the periods covering the periods of both import substitution and trade reform between 1973 and 1985. Despite this effect was still positive, its magnitude seems to have dropped drastically in the period of 19851990 where the Turkish economy was open to international markets. This undistinguished growth performance of foreign trade was because of increased import competition in final demand and intermediate goods. Our findings implicitly show that output gains created by trade in the Turkish economy appear to have been temporary, possible only in the early years of reforms. However, this does not mean that trade reform itself was unsuccessful. This undistinguished performance of trade in terms of creating extra domestic production might be related to macroeconomic environment. Fiscal expansion, overvaluation of $T L$ in some periods and macroeconomic uncertainty that discourage domestic production may also be taken responsible for unimpressive 
growth performance of trade. Empirical results also show that the employment generation capacity of the Turkish economy drastically declined in the postliberalisation period. Despite neoclassical expectations, the reform period after 1982 witnessed large factor substitution against labour, even in the tradeable goods sector. Additionally, labour demand also appears to response to output growth less in the post-liberalisation period than before.

\section{References}

Albala-Bertrand, J.M. (1999), "Structural Change in Chile: 1960-90", Economic System Research 11 (3): 301-319.

Baysan, T. and C. Blitzer (1990), "Turkey's Trade Liberalisation in the 1980 os and Prospects for its Sustainability", in T. Arıcanlı and D. Rodrik (eds.), The Political Economy of Turkey: Debt, Adjustment and Sustainability, pp. 9-36, (London: MacMillan Press).

Bilginsoy, C. (1993), "Inflation, growth, and import bottlenecks in the Turkish manufacturing industry", Journal of Development Economics 42: 111-131.

Celasun, M., (1989), "Income Distribution and Employment Aspects of Turkey's post 1980 Adjustment", METU Studies on Development 16 (3-4): 1-31.

Celasun, M. and D. Rodrik (1989), "Debt, Adjustment and Growth: Turkey", in J.D. Sachs and S.M. Collins (eds.), Developing Country Debt and Economic Performance: Country Studies-Indonesia, Korea, Philippines, Turkey, (Chicago: The university of Chicago Press).

Chenery, H., S. Shishido and T. Watanabe (1962), "The Pattern of Japanese Growth 191454", Econometrica 30: 98-131.

Feldman, McClain and Palmer (1987), "Sources of Structural Change in the United States 1963-1978: An Input-Output Perspective”, Review of Economics and Statistics 69: 503-510.

Günçavdl, Ö. and S. Küçükçifçi (2001), "Foreign Trade and Factor Intensity in an Open Developing Country: An Input-Output Analysis for Turkey”, Russian \& East European Finance and Trade 37 (1): 75-88.

Günçavdı, Ö., S. Küçükçifçi and A. MacKay (2001), "Adjustment, Stabilisation and the Analysis of the Employment Structure in Turkey: An Input-Output Approach", Discussion Papers in Management Engineering No. 01/11, (Istanbul: Istanbul Technical University).

Günlük-Şenesen, G. (1998), "An Input-Output Analysis of Employment Structure in Turkey: 1973-1990", Economic Research Forum Conference for Arab Countries, Iran and Turkey Working Paper 9809, Cairo.

Gregory, M., B. Zissimos and C. Greenhalgh (2001), "Jobs for the Skilled: How Technology, Trade and Domestic Demand Changed the Structure of UK Employment, 1979-90", Oxford Economic Papers 53, 20-46.

Gregory, M. and C. Greenhalgh (1997), "International Trade, Deindustrialization and Labour Demand: An Input-Output Study for the UK (1979-90)", in J. Borkakoti and C. Milner (eds.), International Trade and Labour Markets, pp. 62-89, (London: MacMillan Press).

Kirkpatrick, C. and Z. Öniş (1991), “Turkey”, in P. Mosley and J. Harrigan and J. Toye (eds.), Aid and Power: The World Bank and Policy-Based Lending, vol. 2, Case Studies, (London: Routledges).

Köse, H. A. and E. Yeldan (1996), "On Sectoral Employment and Wage Structure in the Turkish Economy”, Mimo. (in Turkish), Bilkent University, Department of Economics, Ankara. 
Krueger, A. O. and O. H. Aktan (1992), Swimming Against the Tide: Turkish Trade Reform in the 1980s, (San Francisco: International Centre for Economic Growth).

Leontief, V. (1951), The Structure of the American Economy 1919-39: An Empirical Application of Equilibrium Analysis, (New York: Oxford University Press).

Martin, J. and J. Evans (1981), "Notes on Measuring the Employment Displacement Effects of Trade by the Accounting Procedure", Oxford Economic Papers 33 (1): 154-164.

Metin-Özcan, K., E. Voyvoda and A. E. Yeldan (2001), "Dynamics of Macroeconomic Adjustment in a Globalized Developing Economy: Growth, Accumulation and Distribution, Turkey 1969-1999”, Canadian Journal of Development Studies 22 (1): 219-253.

Rodrik, D. (1999), The New Global Economy and Developing Countries: Making Openness Work, Policy Essay No. 24, (Washington, DC: Overseas Development Council).

Olgun, H. and S. Togan, (1990), "Trade Liberalisation and the Structure of Protection in Turkey in the 1980s: A Quantitative Analysis", Weltwirtschaftliches Archiv 127 (1): 152-169.

Özar, Ș. (1995), “The Informal Sector in Turkey”, paper presented at ERF Conference, December 1-3, 1995, Aswan, Egypt.

State Institute Of Statistics (2002), The Input-Output Structure of the Turkish Economy, (Ankara: SIS).

State Institute of Statistics (1998), Household Labour Force Survey Results, (Ankara: SIS).

State Planning Organisation (2002), Economic and Social Indicators (Ankara: SPO).

Yeldan. E. (2000), "The Impact of Financial Liberalisation and the Rise of Financial Rents on Income Inequality: The Case of Turkey", Working Papers No. 206, The United Nations University, World Institute for Development Economics Research (WIDER), November.

Yentürk, N. (1997), "Wages, Employment and Accumulation in the Turkish Economy" (in Turkish), Working Papers, (Istanbul: Friedrich Ebert Foundation).

Appendix A: Derivation of Equation (9) in Detail

We start the formal derivation from equation (7)

$$
\mathbf{x}=(\mathbf{I}-\mathbf{h A})^{-1}(\mathbf{s f}+\mathbf{e})
$$

For simplicity and tractability, let $\mathbf{D}=(\mathbf{I}-\mathbf{h A})$ and $\mathbf{g}=(\mathbf{s} \mathbf{f}+\mathbf{e})$, and write equation (A-1) as follows:

$$
\mathbf{x}=\mathbf{D}^{-1} \mathbf{g}
$$


Equation (A-2) holds for any point in time with $\mathbf{x}, \mathbf{A}, \mathbf{f}, \mathbf{e}, \mathbf{h}$ and $\mathbf{s}$. Then differencing (A-2) yields

$$
\Delta \mathbf{x}=\mathbf{x}_{\mathbf{1}}-\mathbf{x}_{0}=\Delta\left(\mathbf{D}^{-\mathbf{1}} \mathbf{g}\right)=\left(\mathbf{D}_{1}^{-1} \mathbf{g}_{1}\right)-\left(\mathbf{D}_{0}^{-1} \mathbf{g}_{0}\right)
$$

Equation (A-3) can be expressed in a way that each terms on the right-hand side of the equation increase by the amounts of $\Delta \mathbf{D}^{-1}$ and $\Delta \mathbf{g}$ respectively between time o to time 1 . We then obtain

$$
\Delta \mathbf{x}=\left(\mathbf{D}_{0}^{-1}+\Delta \mathbf{D}^{-1}\right)\left(\mathbf{g}_{0}+\Delta \mathbf{g}\right)-\mathbf{D}_{0}^{-1} \mathbf{g}_{0}
$$

Upon expanding (B-4), we get

$$
\Delta \mathbf{x}=\mathbf{D}_{0}^{-1} \mathbf{g}_{0}+\mathbf{D}_{0}^{-1} \Delta \mathbf{g}+\Delta \mathbf{D}^{-1} \mathbf{g}_{0}+\Delta \mathbf{D}^{-1} \Delta \mathbf{g}-\mathbf{D}_{0}^{-1} \mathbf{g}_{0}
$$

Cancelling out the similar terms, we finally derive the following expression:

$$
\Delta \mathbf{x}=\mathbf{D}_{0}^{-1} \Delta \mathbf{g}+\Delta \mathbf{D}^{-1} \mathbf{g}_{0}+\Delta \mathbf{D}^{-1} \Delta \mathbf{g}
$$

In calculating equation (A-6), it is quite important the way we handle the last interactive term (see Martin and Evans, 1981). Some similar studies in the literature recognise the presence of the last term, but none explicitly calculate it, preferring instead to calculate it as a residual. However, we here follow a different way. In the present context, we assume that either the first or the second term on the right hand side of (A-6) can compromise this last term. If the first term includes the last term, then equation (A-6) become weighted by the terminal year of the structural $\mathbf{D}^{-1}$ and the base year of the volume $\mathbf{g}$, and vice versa if the this term is absorbed by the second one. This is rather similar to Paasche and Laspeyres index weightings respectively. Given this explanation, equation (A-6) respectively can be re-written as follows:

$$
\begin{aligned}
& \Delta \mathbf{x}=\mathbf{D}_{1}^{-1} \Delta \mathbf{g}+\Delta \mathbf{D}^{-1} \mathbf{g}_{0} \\
& \Delta \mathbf{x}=\mathbf{D}_{0}^{-1} \Delta \mathbf{g}+\Delta \mathbf{D}^{-1} \mathbf{g}_{1}
\end{aligned}
$$

Despite the fact that the calculations using both weighting yield the analogous, we use the Laspeyres weighting for presentation. However, the same derivation can be repeated for the Paasche weighting. For our present purpose, the first term on the right-hand side of (A-8) can be decomposed as follows:

$$
\mathbf{D}_{0}^{-1} \Delta \mathbf{g}=\mathbf{D}_{0}^{-1}\left[\left(\mathbf{s}_{1} \mathbf{f}_{1}+\mathbf{e}_{1}\right)-\left(\mathbf{s}_{0} \mathbf{f}_{0}+\mathbf{e}_{0}\right)\right]
$$

Adding and subtracting the term $\mathbf{s}_{\mathbf{1}} \mathbf{f}_{1}$ from the right-hand side of (A-9) yields:

$$
\mathbf{D}_{0}^{-1} \Delta \mathbf{g}=\mathbf{D}_{0}^{-1}\left(\Delta \mathbf{s}_{1}+\mathbf{s}_{0} \Delta \mathbf{f}+\Delta \mathbf{e}\right)
$$

The second-term on the right-hand side of (A-8), on the other hand, can be decomposed as:

$$
\Delta \mathbf{D}^{-1} \mathbf{g}_{1}=\left(\mathbf{D}_{1}^{-1}-\mathbf{D}_{0}^{-1}\right) \mathbf{g}_{1}
$$

Since multiplying the first and the second term in the bracket on the right-hand side of (A-11) by $\left(\mathbf{D}_{0}{ }^{-1} \mathbf{D}_{0}\right)$ and $\left(\mathbf{D}_{1} \mathbf{D}_{1}^{-1}\right)$ does not change equation (A-11), the following can also be written:

$$
\Delta \mathbf{D}^{-1} \mathbf{g}_{1}=\left(\mathbf{D}_{0}^{-1} \mathbf{D}_{0} \mathbf{D}_{1}^{-1}-\mathbf{D}_{0}^{-1} \mathbf{D}_{1} \mathbf{D}_{1}^{-1}\right) \mathbf{g}_{1}
$$

Upon re-written (A-12),

$$
\Delta \mathbf{D}^{-1} \mathbf{g}_{1}=\mathbf{D}_{0}^{-1}\left(\mathbf{D}_{0} \mathbf{D}_{1}^{-1}-\mathbf{D}_{1} \mathbf{D}_{1}^{-1}\right) \mathbf{g}_{1}
$$


From (A-13), the following can also be derived:

$$
\Delta \mathbf{D}^{-1} \mathbf{g}_{1}=\mathbf{D}_{0}^{-1}\left(\mathbf{D}_{0}-\mathbf{D}_{1}\right) \mathbf{D}_{1}^{-1} \mathbf{g}_{1}
$$

From equation (A-2), let $\mathbf{D}_{1}^{-1} \mathbf{g}_{1}=\mathbf{x}_{1}$ and write (A-14) as follows:

$$
\Delta \mathbf{D}^{-1} \mathbf{g}_{1}=\mathbf{D}_{0}^{-1}\left(\mathbf{D}_{0}-\mathbf{D}_{1}\right) \mathbf{x}_{1}
$$

Substituting the definition of $\mathbf{D}_{0}$ and $\mathbf{D}_{1}$ in the (A-15) yields

$$
\Delta \mathbf{D}^{-1} \mathbf{g}_{1}=\mathbf{D}_{0}^{-1}\left[\left(\mathbf{I}-\mathbf{h}_{0} \mathbf{A}_{0}\right)-\left(\mathbf{I}-\mathbf{h} \mathbf{A}_{1}\right)\right] \mathbf{x}_{1}
$$

Re-arranging (A-16) gives us equation (A-17) below

$$
\begin{gathered}
\Delta \mathbf{D}^{-1} \mathbf{g}_{1}=\mathbf{D}_{0}^{-1}\left(\mathbf{I}-\mathbf{h}_{0} \mathbf{A}_{0}-\mathbf{I}+\mathbf{h}_{1} \mathbf{A}_{1}\right) \mathbf{x}_{1} \\
\Delta \mathbf{D}^{-1} \mathbf{g}_{1}=\mathbf{D}_{0}^{-1}\left(\mathbf{h}_{1} \mathbf{A}_{1}-\mathbf{h}_{0} \mathbf{A}_{0}\right) \mathbf{x}_{1}
\end{gathered}
$$

Adding and subtracting the same term $\mathbf{h}_{\mathrm{o}} \mathbf{A}_{1}$ from (A-17),

$$
\Delta \mathbf{D}^{-1} \mathbf{g}_{1}=\mathbf{D}_{0}^{-1}\left(\mathbf{h}_{1} \mathbf{A}_{1}-\mathbf{h}_{0} \mathbf{A}_{0}+\mathbf{h}_{0} \mathbf{A}_{1}-\mathbf{h}_{0} \mathbf{A}_{1}\right) \mathbf{x}_{1}
$$

Re-arranging the resulting equation (A-18) gives,

$$
\Delta \mathbf{D}^{-1} \mathbf{g}_{1}=\mathbf{D}_{0}^{-1}\left(\Delta \mathbf{h} \mathbf{A}_{1} \mathbf{x}_{1}+\mathbf{h}_{0} \Delta \mathbf{A} \mathbf{x}_{1}\right)
$$

Finally substituting (A-10) and (A-19) into (A-8) yields the following:

$$
\Delta \mathbf{x}=\mathbf{D}_{0}^{-1}\left(\Delta \mathbf{s}_{1}+\mathbf{s}_{0} \Delta \mathbf{f}+\Delta \mathbf{e}\right)+\mathbf{D}_{0}^{-1}\left(\Delta \mathbf{h} \mathbf{A}_{1} \mathbf{x}_{1}+\mathbf{h}_{0} \Delta \mathbf{A} \mathbf{x}_{1}\right)
$$

Letting $\mathbf{D}_{0}^{-1}=\mathbf{R}_{0}$ we can derive equation (9b) in the text:

$$
\Delta \mathbf{x}=\mathbf{R}_{0} \Delta \mathbf{s} \mathbf{f}_{1}+\mathbf{R}_{0} \mathbf{s}_{0} \Delta \mathbf{f}+\mathbf{R}_{0} \Delta \mathbf{e}+\mathbf{R}_{0} \Delta \mathbf{h} \mathbf{A}_{1} \mathbf{x}_{1}+\mathbf{R}_{0} \mathbf{h}_{0} \Delta \mathbf{A} \mathbf{x}_{1}
$$

Using Paasche weighting the derivation of equation (9a) is also analogous to (A-21).

\section{Appendix B: Price Adjustment Procedure}

The examination of the effects of structural changes in the economy requires an interpemporal comparison by handling changes in price levels. Using two input-output matrices for different years in current prices, we attempt to adjust coefficient matrices for $s$ based matrices to the base year $t$ $(s>t)$ (e.g. see Günlük-Şenesen and Küçükçifçi, 1994). The deflating procedure involves expressing $\mathbf{A}_{s}$, the matrix of technical coefficients, in the price of the year $t$. We define $\mathbf{A}_{s}{ }^{t}$ as $\mathbf{A}_{s}$ deflated with year $s$ prices, so that

$$
\mathbf{A}_{\mathrm{s}}{ }^{\mathrm{t}}=\mathbf{P}_{\mathrm{s}}{ }^{-1} \mathbf{A}_{\mathrm{s}} \mathbf{P}_{\mathrm{s}}
$$

where $\mathbf{P}_{\mathrm{s}}$ is the diagonal matrix of industrial price indices capturing changes in price levels from year $t$ to $s$. From A-1, the typical element of $\mathbf{A}_{s}{ }^{t}$ is 


$$
a_{s, i j}^{t}=\frac{x_{s, i j}}{x_{s, j}} \frac{P_{s, j}}{P_{s, i}}
$$

where $P_{s, i}$ and $P_{s, j}$ are changes in industrial price indices of sector $i$ and sector $j$ from year $t$ to year $s$ respectively, and the $\left(P_{s, j} / P_{s, i}\right)$ term on the right-hand side captures the relative prices from year $t$ to year $s$. 


\section{Appendix C: The Seven-Sector Aggregation}

The Turkish input-output tables before 1996 comprised sixty-four sectors. The available latest table, on the other hand, possesses 97 sectors. Due to lack of the data on the price indices at this aggregation level, we aggregated sectors to the 24 sectors. However, it has been necessary to aggregate them further to 7 sectors to examine some hypothesis advanced in the text. In what follows, we first present the aggregation of the 64564 input-output table to the 24524 one, then introduce the smaller table with further aggregation to 7 sectors.

The sectors in the 24524 tables

\begin{tabular}{|c|c|c|}
\hline SECTORS & $\begin{array}{r}\text { Sector numbers in } \\
\text { the } 64564 \text { input- } \\
\text { output table }\end{array}$ & $\begin{array}{r}\text { Sector numbers in } \\
\text { the } 97597 \text { input- } \\
\text { output table }\end{array}$ \\
\hline 1-Agriculture & $1-4$ & $1-7$ \\
\hline 2- Mining & $5-10$ & $8-12$ \\
\hline 3-Food-Beverage & $11-19$ & $13-25$ \\
\hline 4-Textiles & $20-24$ & $26-32$ \\
\hline 5-Wood-Furniture & $25-26$ & $33-34$ and 67 \\
\hline 6- Paper-Printing & $27-28$ & $35-37$ \\
\hline 7-Chemicals & $29-31$ & $39-43$ \\
\hline 8- Oil-Refining & $32-33$ & 38 \\
\hline 9- Rubber-Plastics & 34-35 & $44-45$ \\
\hline 10- Glass-Cement & $36-38$ & $46-49$ \\
\hline 11- Iron-Steel & $39-40$ & $50-52$ \\
\hline 12- Metal Product & 41 & $53-54$ \\
\hline 13-Machinery & $42-43$ & $55-58$ \\
\hline 14-Electrical-Machinery & 44 & $59-60$ \\
\hline 15- Transportation-Vehicles & $45-48$ & $62-66$ \\
\hline 16- Other manufacturing & 49 & 61 and 68 \\
\hline 17- Utilities & $50-51$ & $69-71$ \\
\hline 18-Construction & $52-53$ & 72 \\
\hline 19- Trade & $54-55$ & $73-77$ \\
\hline 20- Transportation Service & $56-60$ & $78-83$ \\
\hline 21- Banking and Insurance & 61 & $84-85$ \\
\hline 22- Personal Services & 62 & $86-95$ \\
\hline 23- Public Services & 63 & 96 \\
\hline 24-Housing & 64 & 97 \\
\hline
\end{tabular}

The sectors in the 757 tables SECTORS

Sector numbers in the 24524 table

I- Primary and extractive sectors

II- Primary manufacturing

III- High technology manufacturing

IV-Other manufacturing

$\mathrm{V}$ - Less tradeable services

VI- More tradeable services

VII- Finance

$1-2$
$3-4-5-6-10-17-18$
$7-8-9-14-15$
$11-12-13-16$
$19-22-23-24$
20
21


Table 1 Main Macroeconomic Indicators

\begin{tabular}{|c|c|c|c|c|c|c|}
\hline & $1973-76$ & $1977-80$ & $1981-83$ & $1984-88$ & $1989-93$ & 1994-96 \\
\hline \multicolumn{7}{|c|}{ (Period Average in \%) } \\
\hline Real GDP growth rate & 7.2 & 1.3 & 4.0 & $5 \cdot 9$ & 5.2 & 3.1 \\
\hline Savings/GDP & 20.8 & 17.3 & 17.3 & 21.7 & 21.9 & 21.4 \\
\hline Investment/GDP & 21.4 & 22.5 & 18.5 & 22.3 & 23.7 & 23.9 \\
\hline Exports/GDP & 3.7 & 3.3 & 7.8 & 11.5 & 9.1 & 13.3 \\
\hline Imports/GDP & 9.2 & 8.6 & 13.7 & 16.4 & 14.7 & 21.1 \\
\hline Total PSBR/GDP ${ }^{1}$ & -- & 6.9 & 4.1 & 4.7 & 9.1 & 7.6 \\
\hline \multicolumn{7}{|l|}{ Main prices } \\
\hline Inflation (average in \%) & 19.2 & 61.9 & 56.6 & 48.5 & 65.1 & 93.4 \\
\hline Real exchange rate ${ }^{2}(\%$ average) & -3.9 & 7.4 & 12.0 & -0.69 & -6.45 & 5.72 \\
\hline Real interest rate (average in \%) & -10.7 & -43.4 & -13.2 & 2.96 & 4.66 & 24.4 \\
\hline
\end{tabular}

${ }^{1} C A B$ and $P S B R$ respectively stand for current account balance and public sector borrowing requirement.

${ }^{2}$ Calculated as $e\left(P^{*} / P\right)$, where $e$ is the nominal exchange rate, $P^{*}$ and $P$ are the consumer price indices

of the USA and Turkey respectively. Negative numbers indicate the overvaluation of currency, and vice versa.

3 This aggregated sector includes agriculture, mining, energy and services.

Sources: Economic and Social Indicators (1950-1998), Ankara: State Planning Organisation, 1997, and F. Özatay (2000) "A Quarterly Macroeconometric Model for a Highly Inflationary and Indebted Country: Turkey”, Economic Modelling 17: 1-11.

Table 2 - The Share of Sectoral Production Levels in GDP (\%)

\begin{tabular}{|lrrrrr|}
\hline & $1968-73$ & $1974-80$ & $1981-85$ & $1986-90$ & (average) \\
Agriculture & 36.1 & 30.5 & 21.7 & 17.7 & 15.6 \\
Manufacturing & 17.7 & 18.7 & 21.9 & 26.2 & 25.6 \\
Services & 35.9 & 39.6 & 48.2 & 46.5 & 45.6 \\
\hline
\end{tabular}

Source: SPO (2000) 
Table 3 - The Shares \& Growth Rates of Sectoral Output (\%)

\begin{tabular}{|c|c|c|c|c|}
\hline & \multicolumn{2}{|c|}{ Output Growth } & \multicolumn{2}{|c|}{ Shares of Sectoral Output } \\
\hline & Overall Period & Annual $^{*}$ & Initial Year & Terminal Year \\
\hline \multicolumn{5}{|c|}{ 1973-1996 } \\
\hline Primary and extractive sectors & 235.0 & 5.4 & 22.6 & 17.8 \\
\hline Primary manufacturing & 282.9 & 6.0 & $27 \cdot 3$ & 24.7 \\
\hline High technology manufacturing & 429.6 & 7.5 & 9.6 & 12.0 \\
\hline Other manufacturing & 424.2 & 7.5 & 7.0 & 8.7 \\
\hline Less tradable services & 377.8 & 7.0 & 23.1 & 26.1 \\
\hline More tradeable services & 399.8 & $7 \cdot 3$ & 8.2 & 9.7 \\
\hline Financial services & 130.0 & 3.7 & 2.2 & 1.2 \\
\hline TOTAL & 324.2 & 6.5 & 100 & 100 \\
\hline \multicolumn{5}{|c|}{$1973-1985$} \\
\hline Primary and extractive sectors & 52.5 & 3.6 & 22.6 & 16.8 \\
\hline Primary manufacturing & 117.7 & 6.7 & $27 \cdot 3$ & 29.0 \\
\hline High technology manufacturing & 138.4 & 7.5 & 9.6 & 11.2 \\
\hline Other manufacturing & 123.7 & 6.9 & 7.0 & 7.7 \\
\hline Less tradable services & 102.7 & 6.1 & 23.1 & 22.9 \\
\hline More tradeable services & 163.9 & 8.4 & 8.2 & 10.6 \\
\hline Financial services & 75.1 & 4.8 & 2.2 & 1.9 \\
\hline & 104.8 & 6.2 & 100 & 100 \\
\hline \multicolumn{5}{|c|}{$1985-1990$} \\
\hline Primary and extractive sectors & 71.0 & 11.3 & 16.8 & 18.9 \\
\hline Primary manufacturing & 44.2 & 7.6 & 29.0 & 27.6 \\
\hline High technology manufacturing & 29.4 & $5 \cdot 3$ & 11.2 & 9.5 \\
\hline Other manufacturing & 47.0 & 8.0 & 7.7 & 7.4 \\
\hline Less tradable services & 61.3 & 10.0 & 22.9 & 24.4 \\
\hline More tradeable services & 54.2 & 9.0 & 10.6 & 10.7 \\
\hline Financial services & 12.5 & 2.4 & 1.9 & 1.4 \\
\hline TOTAL & 51.7 & 8.7 & 100 & 100 \\
\hline \multicolumn{5}{|c|}{ 1990-1996 } \\
\hline Primary and extractive sectors & 28.5 & 4.3 & 18.9 & 17.8 \\
\hline Primary manufacturing & 22.0 & 3.4 & 27.6 & 24.7 \\
\hline High technology manufacturing & 71.6 & 9.4 & 9.5 & 12.0 \\
\hline Other manufacturing & 59.5 & 8.1 & $7 \cdot 4$ & 8.7 \\
\hline Less tradable services & 46.1 & 6.5 & 24.4 & 26.1 \\
\hline More tradeable services & 22.9 & 3.5 & 10.7 & $9 c ̧ 7$ \\
\hline Financial services & 16.8 & 2.6 & 1.4 & 1.2 \\
\hline TOTAL & 36.6 & $5 \cdot 3$ & 100 & 100 \\
\hline
\end{tabular}

*Annual growth rates are calculated as geometric average of each period. 
Table 4a -The Sources of Changes in Gross Output: Laspeyres Weighting (\%)

\begin{tabular}{|c|c|c|c|c|c|}
\hline SECTORS & $\begin{array}{r}\text { Final } \\
\text { demand }\end{array}$ & $\begin{array}{r}\text { Exports } \\
\text { demand }\end{array}$ & $\begin{array}{r}\text { Import } \\
\text { substitution in } \\
\text { final demand }\end{array}$ & $\begin{array}{r}\text { Import } \\
\text { substitution in } \\
\text { intermediate } \\
\text { goods }\end{array}$ & $\begin{array}{l}\text { Changes in } \\
\text { Technology }\end{array}$ \\
\hline \multicolumn{6}{|c|}{$1973-1996$} \\
\hline Primary and extractive sectors & 99.5 & 17.3 & 12.4 & -12.2 & -17.1 \\
\hline Primary manufacturing & 74.8 & 21.7 & 4.4 & -4.0 & 3.2 \\
\hline High technology manufacturing & 71.0 & $27 \cdot 3$ & 8.0 & $-5 \cdot 7$ & -0.5 \\
\hline Other manufacturing & 50.8 & 25.1 & 20.2 & -6.8 & 10.8 \\
\hline Less tradable services & 79.1 & 12.5 & 1.1 & -0.7 & 8.1 \\
\hline More tradeable services & 58.2 & 27.7 & 1.7 & -1.1 & $13 \cdot 5$ \\
\hline Financial services & 211.9 & 52.0 & 16.7 & -12.0 & -168.7 \\
\hline TOTAL & 76.8 & 20.4 & 6.6 & $-4 \cdot 7$ & 0.9 \\
\hline \multicolumn{6}{|c|}{$1973-1985$} \\
\hline Primary and extractive sectors & 95.6 & 27.8 & 42.0 & -19.2 & -46.2 \\
\hline Primary manufacturing & 77.0 & 22.8 & 3.4 & -2.7 & -0.6 \\
\hline High technology manufacturing & 65.0 & 22.7 & $-5 \cdot 9$ & 17.1 & 1.1 \\
\hline Other manufacturing & 28.2 & 50.9 & $25 \cdot 3$ & -2.8 & -1.7 \\
\hline Less tradable services & 89.2 & 14.5 & 1.1 & 0.1 & -5.0 \\
\hline More tradeable services & 56.9 & 30.1 & 1.4 & -0.1 & 11.8 \\
\hline Financial services & 109.4 & 37.8 & 11.1 & -1.5 & -56.7 \\
\hline TOTAL & $74 \cdot 3$ & 25.0 & $7 \cdot 7$ & -1.1 & -5.9 \\
\hline \multicolumn{6}{|c|}{$1985-1990$} \\
\hline Primary and extractive sectors & 111.7 & 2.5 & -22.1 & -4.0 & 11.9 \\
\hline Primary manufacturing & 79.9 & 2.6 & 2.1 & -0.6 & 16.1 \\
\hline High technology manufacturing & 57.5 & 10.7 & 59.9 & -37.6 & $9 \cdot 5$ \\
\hline Other manufacturing & 18.5 & -9.1 & 49.1 & -4.5 & 46.1 \\
\hline Less tradable services & 76.7 & 3.5 & 1.1 & -0.6 & 19.3 \\
\hline More tradeable services & 73.1 & 7.8 & 1.6 & -1.4 & 18.9 \\
\hline Financial services & $375 \cdot 9$ & -10.6 & 18.2 & -19.2 & -264.3 \\
\hline TOTAL & 81.2 & 3.1 & 3.2 & -4.2 & 16.7 \\
\hline \multicolumn{6}{|c|}{ 1990-1996 } \\
\hline Primary and extractive sectors & $93 \cdot 3$ & 23.7 & 0.7 & $-14 \cdot 3$ & $-3 \cdot 3$ \\
\hline Primary manufacturing & 72.2 & 48.0 & 1.3 & -6.9 & -14.6 \\
\hline High technology manufacturing & 122.6 & 37.7 & -27.6 & -19.3 & $-13 \cdot 3$ \\
\hline Other manufacturing & 163.5 & 29.5 & $-75 \cdot 0$ & -13.5 & -4.5 \\
\hline Less tradable services & 79.5 & 19.7 & -2.9 & -1.6 & 5.2 \\
\hline More tradeable services & 80.4 & 62.0 & -10.5 & -5.2 & -26.7 \\
\hline Financial services & 211.0 & 74.8 & -19.3 & -15.1 & -151.5 \\
\hline TOTAL & 99.0 & 32.7 & -15.6 & -9.4 & -7.1 \\
\hline
\end{tabular}


Table 4b -The Sources of Changes in Gross Output: Paasche Weighting (\%)

\begin{tabular}{|c|c|c|c|c|c|}
\hline SECTORS & $\begin{array}{r}\text { Final } \\
\text { demand }\end{array}$ & $\begin{array}{r}\text { Exports } \\
\text { demand }\end{array}$ & $\begin{array}{r}\text { Import } \\
\text { substitution in } \\
\text { final demand }\end{array}$ & $\begin{array}{r}\text { Import } \\
\text { substitution in } \\
\text { intermediate } \\
\text { goods }\end{array}$ & $\begin{array}{r}\text { Changes in } \\
\text { Technology }\end{array}$ \\
\hline \multicolumn{6}{|c|}{$1973-1996$} \\
\hline Primary and extractive sectors & 92.0 & 12.0 & 3.1 & -3.8 & -3.2 \\
\hline Primary manufacturing & 77.4 & 21.5 & 1.3 & -0.9 & 0.8 \\
\hline High technology manufacturing & 74.9 & $24 \cdot 7$ & 1.8 & -1.5 & 0.1 \\
\hline Other manufacturing & 67.8 & 24.8 & $5 \cdot 9$ & -1.5 & 2.9 \\
\hline Less tradable services & 84.4 & 13.6 & 0.3 & -0.2 & 1.9 \\
\hline More tradeable services & 67.4 & 29.4 & 0.5 & -0.3 & 3.0 \\
\hline Financial services & 117.7 & 22.4 & 1.6 & -1.4 & -40.3 \\
\hline TOTAL & 79.8 & 19.3 & 1.7 & -1.3 & 0.4 \\
\hline \multicolumn{6}{|c|}{$1973-1985$} \\
\hline Primary and extractive sectors & 80.8 & 19.9 & 30.2 & -6.5 & -24.4 \\
\hline Primary manufacturing & 76.9 & 22.5 & 2.0 & -1.3 & -0.1 \\
\hline High technology manufacturing & 67.8 & 23.6 & -1.6 & 6.7 & $3 \cdot 5$ \\
\hline Other manufacturing & 29.4 & 49.8 & 22.6 & -2.1 & 0.3 \\
\hline Less tradable services & 88.0 & 13.8 & 0.5 & 0.1 & -2.4 \\
\hline More tradeable services & 61.7 & 31.4 & 1.3 & 0.0 & 5.6 \\
\hline Financial services & 90.1 & 29.8 & 6.8 & -0.1 & -26.6 \\
\hline TOTAL & 73.0 & $23 \cdot 9$ & 6.1 & -0.4 & -2.6 \\
\hline \multicolumn{6}{|c|}{$1985-1990$} \\
\hline Primary and extractive sectors & 103.2 & 2.6 & -10.5 & -3.3 & 7.9 \\
\hline Primary manufacturing & 84.1 & 2.7 & 2.1 & -0.3 & 11.5 \\
\hline High technology manufacturing & $37 \cdot 3$ & 9.9 & 70.4 & -23.8 & 6.2 \\
\hline Other manufacturing & 25.7 & -8.2 & 52.6 & $-4 \cdot 9$ & 34.9 \\
\hline Less tradable services & 81.3 & $3 \cdot 7$ & 1.9 & -0.5 & 13.5 \\
\hline More tradeable services & 76.2 & 7.7 & $3 \cdot 3$ & -0.9 & $13 \cdot 7$ \\
\hline Financial services & 308.0 & $-14 \cdot 3$ & 9.7 & -6.8 & -196.6 \\
\hline TOTAL & 80.9 & 3.2 & 7.2 & -3.0 & 11.8 \\
\hline \multicolumn{6}{|c|}{ 1990-1996 } \\
\hline Primary and extractive sectors & 89.8 & 21.6 & 1.6 & -11.5 & -1.5 \\
\hline Primary manufacturing & 65.7 & 45.8 & 3.5 & -4.5 & -10.5 \\
\hline High technology manufacturing & 94.1 & $33 \cdot 4$ & -8.9 & -13.0 & -5.6 \\
\hline Other manufacturing & 106.2 & 27.1 & -24.6 & -5.5 & -3.2 \\
\hline Less tradable services & $77 \cdot 5$ & 19.8 & -0.8 & -0.9 & 4.3 \\
\hline More tradeable services & 64.2 & 59.1 & -2.4 & -2.6 & -18.3 \\
\hline Financial services & 159.8 & 60.5 & $-3 \cdot 3$ & -8.2 & -108.9 \\
\hline TOTAL & 83.6 & 30.7 & -4.2 & -6.0 & -4.0 \\
\hline
\end{tabular}


Table 5 - The Trade-related sources of output growth by sector

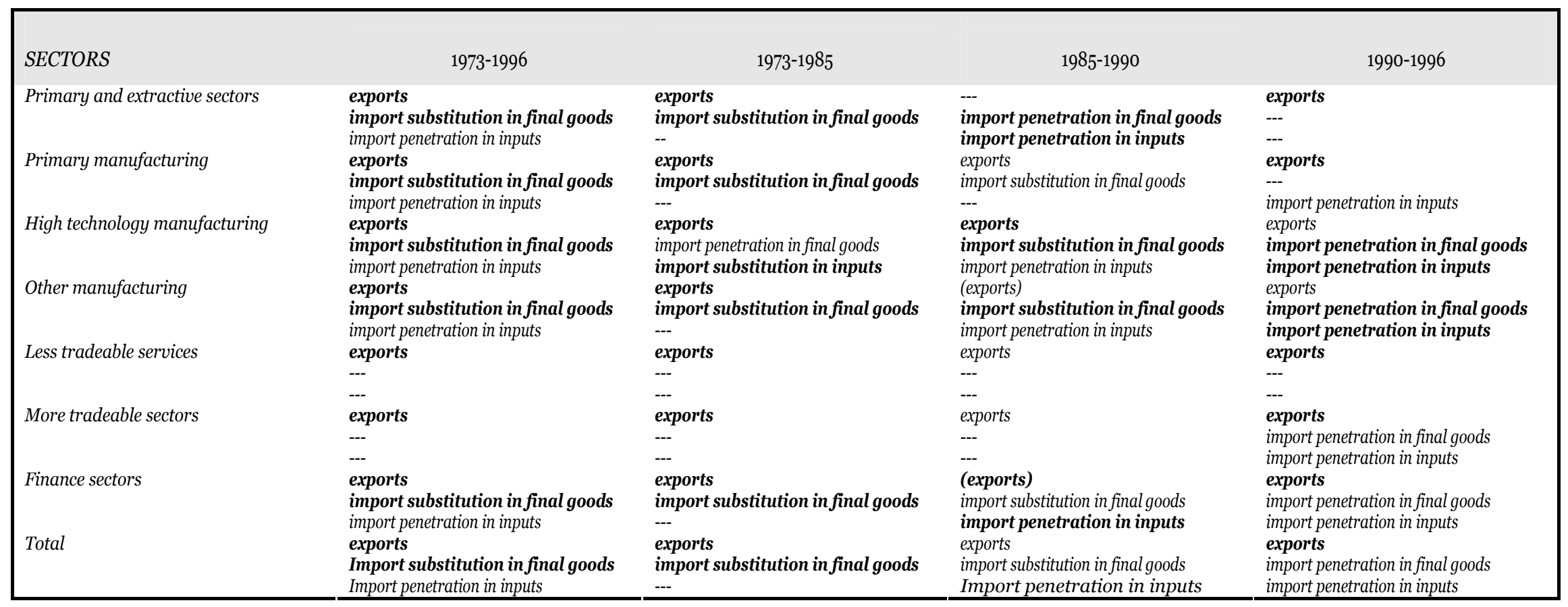

Notes: An expression in each cell of the table shows only the trade-related sources of sectoral output growth. Expressions written bold indicate the dominant positive and negative effect on output growth. Exports in brackets represent the substantial negative effects. 
7 July 2008.

Table 6a - Decomposition of change in employment: Laspeyres Weighting (\%)

\begin{tabular}{|c|c|c|c|}
\hline & $\begin{array}{r}\text { Change in gross } \\
\text { output }\end{array}$ & $\begin{array}{l}\text { Change in } \\
\text { employment } \\
\text { income ratio }\end{array}$ & $\begin{array}{l}\text { Total change in } \\
\text { employment }\end{array}$ \\
\hline \multicolumn{4}{|c|}{$1973-1996$} \\
\hline $\begin{array}{l}\text { Primary \& Extractive sector } \\
\text { Primary manufacturing } \\
\text { Technology-intensive manufacturing } \\
\text { Other manufacturing } \\
\text { Less tradeable } \\
\text { More tradeable } \\
\text { Finance } \\
\text { Total }\end{array}$ & $\begin{array}{r}234.96 \\
282.90 \\
429.58 \\
424.15 \\
377.82 \\
399.77 \\
130.01 \\
\mathbf{3 2 4 . 2 4}\end{array}$ & $\begin{array}{r}-225.22 \\
-193.09 \\
-324.68 \\
-383.66 \\
-245.45 \\
-324.07 \\
246.79 \\
-\mathbf{2 7 6 . 7 4}\end{array}$ & $\begin{array}{r}9.74 \\
89.82 \\
104.90 \\
40.48 \\
132.38 \\
75.70 \\
376.80 \\
47.50\end{array}$ \\
\hline \multicolumn{4}{|c|}{$1973-1985$} \\
\hline $\begin{array}{l}\text { Primary \& Extractive sector } \\
\text { Primary manufacturing } \\
\text { Technology-intensive manufacturing } \\
\text { Other manufacturing } \\
\text { Less tradeable } \\
\text { More tradeable } \\
\text { Finance } \\
\text { Total }\end{array}$ & $\begin{array}{r}52.45 \\
117.67 \\
138.43 \\
123.70 \\
102.74 \\
163.89 \\
75.08 \\
104.77\end{array}$ & $\begin{array}{r}-53.31 \\
-73.96 \\
-86.11 \\
-93.75 \\
-40.44 \\
-121.66 \\
174.99 \\
\mathbf{- 8 4 . 6 0}\end{array}$ & $\begin{array}{r}-0.86 \\
43.70 \\
52.32 \\
29.95 \\
62.30 \\
42.23 \\
250.08 \\
\mathbf{2 0 . 1 7}\end{array}$ \\
\hline \multicolumn{4}{|c|}{$1985-1990$} \\
\hline $\begin{array}{l}\text { Primary \& Extractive sector } \\
\text { Primary manufacturing } \\
\text { Technology-intensive manufacturing } \\
\text { Other manufacturing } \\
\text { Less tradeable } \\
\text { More tradeable } \\
\text { Finance } \\
\text { Total }\end{array}$ & $\begin{array}{r}70.99 \\
44.23 \\
29.44 \\
46.94 \\
61.33 \\
54.16 \\
12.50 \\
\mathbf{5 1 . 6 5}\end{array}$ & $\begin{array}{r}-66.41 \\
-39.43 \\
-23.24 \\
-29.70 \\
-40.08 \\
-42.58 \\
-1.92 \\
-42.53\end{array}$ & $\begin{array}{r}4.58 \\
4.81 \\
6.20 \\
17.24 \\
21.25 \\
11.58 \\
10.59 \\
\mathbf{9 . 1 1}\end{array}$ \\
\hline \multicolumn{4}{|c|}{ 1990-1996 } \\
\hline $\begin{array}{l}\text { Primary \& Extractive sector } \\
\text { Primary manufacturing } \\
\text { Technology-intensive manufacturing } \\
\text { Other manufacturing } \\
\text { Less tradeable } \\
\text { More tradeable } \\
\text { Finance } \\
\text { Total }\end{array}$ & $\begin{array}{r}28.50 \\
21.96 \\
71.59 \\
59.46 \\
46.09 \\
22.85 \\
16.77 \\
\mathbf{3 6 . 6 2}\end{array}$ & $\begin{array}{r}-22.65 \\
4.07 \\
-44.93 \\
-67.25 \\
-28.01 \\
-12.14 \\
6.39 \\
\mathbf{- 2 4 . 1 3}\end{array}$ & $\begin{array}{r}5.85 \\
26.03 \\
26.66 \\
-7.79 \\
18.08 \\
10.72 \\
23.16 \\
12.49\end{array}$ \\
\hline
\end{tabular}


Table 6b - Decomposition of change in employment: Paasche Weighting (\%)

\begin{tabular}{|c|c|c|c|}
\hline & $\begin{array}{r}\text { Change in gross } \\
\text { output }\end{array}$ & $\begin{array}{l}\text { Change in } \\
\text { employment } \\
\text { income ratio }\end{array}$ & $\begin{array}{l}\text { Total change in } \\
\text { employment }\end{array}$ \\
\hline \multicolumn{4}{|c|}{ 1973-1996 } \\
\hline Primary \& Extractive sector & 70.15 & -61.27 & 8.88 \\
\hline Primary manufacturing & 73.88 & -26.57 & $47 \cdot 32$ \\
\hline Technology-intensive manufacturing & 81.12 & -29.92 & 51.20 \\
\hline Other manufacturing & 80.92 & -52.11 & 28.82 \\
\hline Less tradeable & 79.07 & -22.11 & 56.97 \\
\hline More tradeable & 79.99 & -36.90 & 13.09 \\
\hline Finance & 56.52 & 22.50 & 79.03 \\
\hline Total & 76.43 & -44.22 & 32.21 \\
\hline \multicolumn{4}{|c|}{$1973-1985$} \\
\hline Primary \& Extractive sector & 34.41 & -35.27 & -0.87 \\
\hline Primary manufacturing & 54.06 & -23.65 & 30.41 \\
\hline Technology-intensive manufacturing & 58.06 & -23.71 & $34 \cdot 35$ \\
\hline Other manufacturing & $55 \cdot 30$ & -32.25 & 23.05 \\
\hline Less tradeable & 50.68 & -12.29 & 38.39 \\
\hline More tradeable & 62.10 & -32.41 & 29.69 \\
\hline Finance & 42.88 & 28.55 & 71.43 \\
\hline Total & 51.16 & $-34 \cdot 38$ & 16.79 \\
\hline \multicolumn{4}{|c|}{$1985-1990$} \\
\hline Primary \& Extractive sector & 41.52 & -37.14 & $4 \cdot 38$ \\
\hline Primary manufacturing & 30.67 & -26.08 & 4.59 \\
\hline Technology-intensive manufacturing & 22.75 & -16.90 & 5.84 \\
\hline Other manufacturing & 31.95 & -17.24 & 14.71 \\
\hline Less tradeable & 38.02 & -20.49 & 17.53 \\
\hline More tradeable & 35.13 & -24.76 & 10.38 \\
\hline Finance & 11.11 & -1.54 & 9.57 \\
\hline Total & 34.06 & $-25 \cdot 71$ & 8.35 \\
\hline \multicolumn{4}{|c|}{ 1990-1996 } \\
\hline Primary \& Extractive sector & 22.1 & -16.65 & $5 \cdot 52$ \\
\hline Primary manufacturing & 18.01 & 2.65 & 20.65 \\
\hline Technology-intensive manufacturing & 41.72 & -20.67 & 21.05 \\
\hline Other manufacturing & 37.29 & $-45 \cdot 74$ & -8.45 \\
\hline Less tradeable & 31.55 & -16.24 & $15 \cdot 31$ \\
\hline More tradeable & 18.60 & -8.92 & 9.68 \\
\hline Finance & $14 \cdot 36$ & 4.44 & 18.80 \\
\hline Total & 26.80 & $-15 \cdot 70$ & 11.11 \\
\hline
\end{tabular}

